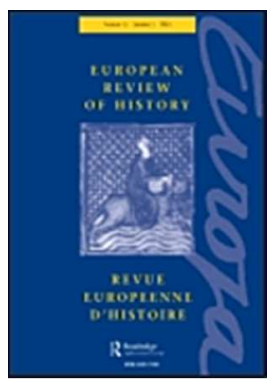

\title{
Re-designing Military Security in Europe: Cooperation and Competition between the European Community and NATO during the early 1980 s
}

\begin{tabular}{|r|l|}
\hline Journal: & European Review of History / revue européenne d histoire \\
\hline Manuscript ID & CERH-2016-0016.R2 \\
\hline Manuscript Type: & Article \\
\hline Keywords: & Cold War, Disarmament, NATO, CSCE, Détente, European Community, EPC \\
\hline \multicolumn{2}{|r}{} \\
\hline
\end{tabular}

SCHOLARONE $^{\text {m }}$

Manuscripts

URL: http://mc.manuscriptcentral.com/cerh Email: 


\title{
Re-designing Military Security in Europe: \\ Cooperation and Competition between the European Community and NATO during the early 1980s
}

\author{
Angela Romano \\ Department of History and Civilization, EUI
}

\begin{abstract}
In the early 1980s, the member states of the European Community ('the Ten') extended their foreign policy cooperation into the field of security and disarmament. They advanced a proposal for a Conference on Disarmament in Europe within the framework of the Conference on Security and Cooperation in Europe process. As disarmament was a preserve and priority concern of NATO, the move engendered both competition and cooperation between NATO and European Political Cooperation (EPC), i.e. the mechanism the Ten used to elaborate common positions. This article analyses these dynamics by paying particular attention to the exchange of ideas between the two forums. It also shows the key role of some West European governments in inspiring competition or promoting cooperation between the two organisations, and the rationales and drivers behind their action. The article proves that Cold War concerns played a key role in this regard: the will to preserve European détente and the need to address domestic opinion critical of an escalation of the East-West confrontation motivated their initiative in the disarmament field. At the same time, concern that the Soviets might exploit divergences across the Atlantic prompted their attempts to secure NATO's cohesion and project a strong image of unity.
\end{abstract}

\section{Keywords \\ Cold War, Disarmament, NATO, EPC, European Community, CSCE, Détente.}

\section{Introduction}

At the opening session of the Conference on Confidence- and Security-Building Measures and Disarmament in Europe (CDE), French Foreign Minister Claude Cheysson declared, 'France hoped for this conference and proposed it. The ten members of the European Community have wanted it, according to the principles presented in their statement of 20 November $1979{ }^{\prime} .{ }^{1}$ Cheysson was speaking on behalf on the ten member states of the European Community (EC), of which France 
held the rotating presidency, to signal that in a key area of Cold War negotiations they had decided to speak with a single voice.

The CDE, which opened in Stockholm on 17 January 1984, was an integral part of the process engendered by the Helsinki Conference on Security and Cooperation in Europe (CSCE) in 1975 and developed through periodic follow-up meetings. The CDE mandate had been agreed at the second of such meetings, held in Madrid in 1980-83; it called for a conference in two phases: the first (in Stockholm) would negotiate and adopt confidence- and security-building measures (CSBMs) designed to reduce the risk of military confrontation in Europe; the second phase would address disarmament measures. The CDE mandate specified that measures should be militarily significant, politically binding, verifiable, and applicable to the whole of Europe, that is Soviet territory up the Ural Mountains. The CDE concluded successfully on 19 September 1986. Its final document, which entered into force in January 1987, adopted such kind of measures and established, for the first time in the Cold War period, the right to conduct on-site inspections of military forces in the field.

That the governments of the EC member states had agreed to deal with military security issues collectively is already impressive. Even more striking is the fact that they launched an initiative in the field and strived to have it adopted. Military security is certainly a domain in which the EC can hardly claim a pioneering role. Officially, only the European Union (EU) created by the 1992 Maastricht Treaty has been provided with a Common Security and Defence Policy. The EC never had competence in these matters, and NATO enjoyed prerogative in the field for decades. Unsurprisingly, there has been to date no historical investigation of the interactions between the EC and NATO in this domain. The dominant narrative has it that the failure to create a European Defence Community and the consequential admission of West Germany into NATO (1955) put an end to attempts at forging a West European actor in the security/military domain; the idea would only re-emerge with the creation of the European Union in the post-Cold War era. ${ }^{2}$ This article demonstrates that this story is incomplete at best; the CDE initiative represents an evident foray into 
a new domain of EC members' cooperation.

Admittedly, their action did not unfold within the supranational framework of the European Community, but within European Political Cooperation (EPC), that is the intergovernmental mechanism for foreign policy coordination set in motion in November 1970. Several historians have explored the question of an EC role as a security actor, and devoted particular attention to EPC, but did not venture in considering military security aspects. ${ }^{3}$ This article contends that in the early 1980s the EC governments became pro-active as a group in the field of disarmament in Europe, the CDE being their signature initiative. It argues that Cold War concerns were the main driver behind their collective engagement in the matter. They were motivated by anxiety about the endurance of détente in Europe, the pursuit and promotion of which had been both at the core of their national foreign policies since the mid-1960s and the main and most successful chapter of their embryonic common foreign policy since 1970. At the same time, they were also driven by the need to counter pacifist movements and the risk of neutralist tendency the latter could promote in domestic public opinion. In addition, it is here argued that divergence with the US administrations on how to shape relations with the Soviets and the European order constantly nourished the EC governments' determination to launch and uphold the CDE initiative. This article acknowledges that the CSCE constituted the framework where EPC's Cold War policy was born and flourished, and maintains that EC governments were thus keen to have the CDE unfold within the forum that had proven so favourable to their unitary action.

The study of intergovernmental discussions leading to the final design of the CDE proposal and its inception provides an excellent case for analysing the EPC/NATO relationship. As disarmament was a central issue in NATO security strategy, the EC governments' action engendered competition between EPC and NATO. At the same time, overlapping membership also made cooperation obvious between the two institutions; all EC member states but Ireland belonged to the Atlantic Alliance, and none of them aimed at marginalising NATO. This article analyses this set of 
interactions by paying particular attention to inter-organisational exchange of ideas on disarmament and European security. It proves that EPC innovated in the field of disarmament, while NATO followed suit and eventually incorporated EPC ideas in its own policy. This study is also concerned with identifying the actors mainly responsible for encouraging competition and/or cooperation. Given the high politics nature of the case under scrutiny, the choice has been to focus on governments and high-rank individuals therein. In so doing, it demonstrates that inter-organisational dynamics also played a formative role in 'high politics' fields such as military security. ${ }^{4}$

The focus on government representatives is also motivated by the intention to contribute a missing piece to the recent historiography of the West's security policy in the 1970s and 1980s, which has much focused on their role. Understandably, most works dealt with SALT negotiations and Euromissiles - whether to analyse bilateral discussions or NATO debates, to reveal the origins of NATO dual-track decision, or to expose its domestic politics rationales. ${ }^{5}$ All these valuable studies invariably focus on nuclear armaments, and completely ignore the CDE proposal. Yet conventional forces imbalance in Europe, with the Soviet Union largely in a dominant position, was part and parcel of West European leaders' fears of a possible decoupling between the United States' and West Europe's security. This article draws attention to this overlooked element of the European security conundrum and the related transatlantic debate.

The article, which bases its analysis on archival sources of EC institutions, NATO, and some member states, unfolds in three steps. It first summarises the security and disarmament negotiations situation at the end of the 1970s, and then offers two sections exploring, respectively, the dynamics of competition and cooperation between EPC and NATO on CDE-related discussions and their outcomes. Each section also highlights the action of specific governments and individuals therein in stimulating such dynamics. In the conclusion, the article offers an assessment of the patterns of interactions between EPC and NATO in which drivers and intended goals are highlighted. 
Before moving to the analysis, it is necessary to clarify some features of the two organisations here under scrutiny. The North Atlantic Treaty of 4 April 1949 created a defensive alliance and equipped it with an institution - the (North Atlantic) Council - where member states' delegates would meet promptly to consider matters concerning security and the implementation of the Treaty. By the mid1970s the Council met in permanent session: weekly at national representatives level, twice per year at foreign ministers level (sometimes accompanied by defence ministers), and on an ad hoc basis at heads of state and government level. ${ }^{6}$ The Alliance's integrated military structure was created after the outbreak of the Korean War in 1950 , which raised the alert about Soviet intentions. ${ }^{7}$ The term 'NATO' has since been used to identify both the Alliance's political apparatus and the military integrated structure. While accepting this use, this article will highlight the difference between the political and military branches whenever necessary.

EPC worked on the principles of 'maximum informality, a commitment to consult but no legal obligation under any circumstances to agree, maximum exchange of information, the attempt always to create consensus and a common view'. ${ }^{8}$ It had been conceived and set up as a separate entity from the European Community to deal with high politics issues without the constraints of Community rules and institutions' competence, but it was a tool of $E C$ members. Moreover, the EC Commission became increasingly involved, and in 1981 the EC foreign ministers adopted the London Report that formally recognised the EPC/EC connection. ${ }^{9}$ EC member states called themselves - and were called by others - 'the Nine' in the years 1972-1980, then 'the Ten' after Greece joined the EC in January 1981 (and so on). So does this article on occasion.

\section{Security and disarmament in Europe in the late 1970s}

From NATO's inception to the early 1960s, Western security strategy had been conceived in terms of the traditional balance of power; the adversary being seen as expansionist, only political and military strength would hold it in check. Things changed after mutual suspicions had brought the world on the edge of nuclear war during the Cuban missiles crisis in 1962. With the adoption of the 
'Report on the Future Tasks of the Alliance' in 1967, the so-called Harmel Report, NATO committed itself to combining military defence with détente; security could be enhanced also by involving the adversary in activities aimed at relaxing tension and by avoiding misconduct in mutual relations. The Harmel Report also called for allies' studies about possible disarmament and practical arm control measures. ${ }^{10}$ Six months later, in June 1968, the North Atlantic Council ministerial meeting in Reykjavik issued an appeal to the Soviet Union and its Warsaw Pact allies for negotiations on Mutual and Balanced Force Reduction in Europe (MBFR). ${ }^{11}$

To be precise, the appeal was issued by the countries participating in the NATO Defence Programme, that is all members but France. Although part of the North Atlantic political organisation, France had left the integrated military command structure in spring 1966 and never participated in NATO's Nuclear Planning Group. The withdrawal had been the last and most dramatic step in President Charles de Gaulle's roadmap to regain France independence in the field of defence, which was instrumental to political assertiveness, after his failed attempts to redress the balance within NATO, which he felt dominated by the Americans. By the mid-1960s France had acquired its own nuclear capability - the Force de Frappe - built to retain independence in the event of a major threat and as an insurance policy in case the United States would not defend Europe. ${ }^{12}$ Subsequent governments maintained this peculiar status of France in NATO and its independent defence policy.

NATO's call for force reduction talks fell on deaf ears, but had a revival when the Warsaw Pact proposed the convening of a conference on European security in March 1969. Western assent to the latter was conditioned to agreements on Ostpolitik treaties, Berlin, and German-German relations, and the opening of the MBFR talks. ${ }^{13}$ The latter were conceived to maintain the existing level of security while reducing its costs, and were of major importance for the Nixon administration's effort to handle domestic pressures for unilateral reduction of troops in Europe. Consequently, the White House bargained bilaterally with the Kremlin, and agreement to launch both negotiations in 
parallel was indeed reached at the Moscow summit of May 1972. The MBFR talks opened in January in Vienna between Warsaw Pact members and NATO states minus France, where President Georges Pompidou upheld de Gaulle's legacy. ${ }^{14}$

The other NATO European members had shown less enthusiasm for the MBFR than the Americans; in addition, they had asked for the topic of military security to be included in the CSCE agenda. Those member states with no troops on the Cold War front in central Europe feared that the MBFR talks could harm their security interests; consequently, they advocated a clear link between these negotiations and the CSCE, in which they would participate with full rights. Italy, Norway, Greece, and Turkey had clearly expressed this view. ${ }^{15}$ Moreover, the EC governments shared a latent yet growing mistrust of their American ally. The Italian and the German governments were most worried by the possibility of the unilateral withdrawal of US troops; they thought that an established MBFR-CSCE link would give the US Congress tangible evidence of the Europeans' willingness to negotiate arms reduction and help forestall unilateral decisions. The Belgian, Dutch, and Luxembourg governments were afraid that their voice would be unheard in bloc-to-bloc negotiations, where the superpowers would obviously play a leading role and marginalise small allies. The British government, traditionally very sensitive to Benelux concerns of this kind, also preferred to give more room to the CSCE, which assured a greater involvement of minor powers as well as neutral European countries, i.e. Switzerland, Sweden, and Austria, whose governments tended to side with the West in multilateral negotiations. ${ }^{16}$ The neutrals had indeed expressed the intention to bring to the CSCE some proposals on military aspects of security, and asked to link MBFR and CSCE negotiations. ${ }^{17}$

NATO discussions about MBFR and CSCE revealed the deterioration of European governments' confidence in the US administration. At the root of their unease was a sense that the White House was increasingly considering the international scenario in the light of its relationship with the Kremlin, and that it was prepared to subordinate the interests of its allies to it. The US-Soviet 
agreement on the limitation of strategic arms (SALT) signed in May 1972 had accentuated the doubts on the US willingness to contemplate the use of nuclear weapons in case of conflict in Europe in a situation of strategic parity with the Soviet Union. Moreover, the US withdrawal from Vietnam and the anxiety to ensure a swift solution to the conflict had exacerbated suspicions, always present in West European capitals, that the Americans would be prepared to sacrifice their allies if they saw it fit with their national interest. In late November 1972, UK Defence Secretary Lord Carrington wrote to Prime Minister Edward Heath about 'a more specific fear that the Americans may have actually reached secret agreements with the USSR on matters like MBFR which are of legitimate concern to NATO as a whole'. ${ }^{18}$ Most EC leaders felt this growing sense of superpower condominium over their heads and had a neat perception of diverging interests across the Atlantic on several issues; this strengthened their determination to agree on common foreign policy within EPC. ${ }^{19}$

Arguably, the determination of EC governments to propose confidence-building measures in Europe was born in the mid-1970s in reaction to NATO's MBFR talks, motivated by European governments' shared sense of marginalisation in European security matters. The idea of negotiating these measures was not original or exclusive to EPC, though. As already mentioned, representatives of the neutral European countries had already advanced some hypotheses during bilateral discussions that preceded the CSCE. ${ }^{20}$ All European countries thought that confidence-building measures would defuse situations such as military manoeuvres and movements of the adversary camp that, though ordinary, could engender suspicion and lead to dangerous pre-emptive action. Most EC governments favoured these measures also to discourage intimidating display of force and increase the political cost of Soviet interventions in Eastern Europe $a ̀$ la Prague $1968 .{ }^{21}$ The coordinated efforts of the delegations of the EC countries and of neutral and non-aligned states succeeded in adding a specific item on such measures to the CSCE negotiations agenda. 
The MBFR talks entered an impasse quite soon after the start in January 1973, mainly because the two opposing parties proved unable to agree on the actual force levels on both sides. ${ }^{22}$ By contrast, the confidence-building aspect of the CSCE had better fortune. The Final Act contained a series of modest measures designed to reduce the 'dangers of armed conflict and of misunderstanding or miscalculation of military activities which could give rise to apprehension' ${ }^{23}$ The document also encouraged voluntary notification of smaller scale military manoeuvres, major military movements, and the invitation of observers to manoeuvres. In the course of the next years, both sides observed the compulsory elements of these provisions fairly rigorously, but the Warsaw Pact proved reluctant to engage on the voluntary notifications. ${ }^{24}$ The CSCE follow-up meeting in Belgrade (4 October 1977 - 8 March 1978) failed to agree on any development, due to renewed superpowers tensions, and stalemate in disarmament talks did not promise any better. This grim situation triggered the CDE proposal.

\section{Competition between EPC and NATO}

From a formal point of view, the CDE proposal was French; it was tabled in the Madrid CSCE follow-up meeting on 9 December 1980 by the French delegation on behalf of its government. It then received immediate backing from the delegations of France's EC partners, and support from NATO non-EC allies, with the exception of the United States. ${ }^{25}$ More substantially, though, the CDE proposal was a key feature of the EC governments' common CSCE policy, approved by the EPC ministerial meeting in November $1979 .{ }^{26}$ Only after this EPC imprimatur was the proposal subjected to NATO endorsement. ${ }^{27}$ In addition, the latter did not rule out EPC engagement on the initiative; EPC remained both a key forum for detailed discussions on the matter and the most committed actor sponsoring the disarmament conference at the Madrid CSCE follow-up meeting.

The French origin of the CDE is almost obvious. According to Veronika Heyde, the deployment of the Soviet SS-20 missiles and ensuing debate on nuclear weapons negotiations convinced President Giscard that France could no longer ignore disarmament talks. In the spring of 1977 the president 
asked the experts of the Centre d'analyse et de prevision (the equivalent of a Planning Staff) to elaborate a proposal that would meet French security requirements. ${ }^{28}$ The core of French experts' considerations was that French nuclear forces should not be included in disarmament negotiations, and that Soviet superiority in conventional forces was a major threat to European security. Consequently, France should only participate in disarmament negotiations involving Soviet 'European' territory and forces. ${ }^{29}$ The French experts conceived the idea of a general conference on disarmament in Europe with an initial focus on confidence-building measures as an alternative to the MBFR talks, which the French government did not attend and saw as fatally flawed. First, MBFR focused on too small an area of Central Europe to be military significant; second, it was concerned with reductions in manpower while neglecting the most threatening element, i.e. the concentration of powerful conventional weaponry in Europe; third, it tackled the problems in the wrong order by seeking to accomplish the most difficult task of reducing forces before building mutual confidence, which the French considered the essential preliminary step. ${ }^{30}$

Less evident are the reasons why EC partners joined in advocating a new initiative that would overlap the MBFR talks, and agreed to promote it under the aegis of EPC rather than as a new NATO-sponsored proposal. The 1957 Treaty of Rome creating the European (Economic) Community did not deal with security and there had been no full-scale attempt since to broaden the scope of the Community's competence to include defence. However, since the early 1970 s the EC governments had started to develop a joint security concept through EPC. Since the latter's inception, most governments had pointed out that security concerns would not be excluded from foreign policy discussions and deliberations; sure enough, EPC dealt with security issues within the scope of the CSCE. The Helsinki Conference was a tremendous learning-by-doing experience that strengthened EC governments' cohesion as a group and trained them in forging a common policy. They were successful in their endeavour, and recognised by the other CSCE participants for their unitary and effective action, which also continued in the ensuing process. ${ }^{31}$ It should not come as a 
surprise, therefore, that they would use again EPC to promote the CDE initiative; they could rely on the combination of training and machinery that had proved effective. Moreover, EPC was already equipped with procedures to deal with NATO. Since 1972 EC governments had developed the practice of coordinating their views in EPC prior to the meetings of the NATO Council and working committees, including those addressing military security issues such as confidencebuilding measures. They usually arrived with EPC-agreed positions and proved often reluctant to modify them to accommodate non-EC NATO allies' views. ${ }^{32}$

A certain degree of competition with NATO was therefore present since EPC's early days. It became more evident by the end of the 1970s, when EPC put more emphasis on security aspects following the raise of East-West tensions. In the second half of the 1970s the Soviet Union had been particularly active in African conflicts (such as Angola and Mozambique), scored a bad record in compliance with CSCE human aspects provisions, and had embarked on a new course of military build-up. More specifically, in the second half of 1976 it had started deploying a new generation of intermediate-range ballistic missiles (SS-20) that could quickly hit designated targets throughout Western Europe. In the United States, President Carter, though committed to continue strategic arms limitation talks (SALT 2), adopted a confrontational stance towards the Soviets in the field of human rights. Carter's stance contributed to sour the relationship between the superpowers, and put disarmament talks in jeopardy. Concerns about East-West tensions engendered by superpowers' behaviour were frequently discussed within EPC and in the European Council, where the EC heads of state and government met for informal discussions of any issue they saw fit. ${ }^{33}$ EPC did not discuss defence issues in the narrow sense, such as military strategy, defence planning and tactics, and command structures, yet it went beyond CSCE confidence-building measures and ventured frequently in NATO's preserve to discuss disarmament. ${ }^{34}$

It was in this context of Cold War tension that French President Valéry Giscard d'Estaing personally presented the idea of a two-phase CDE at the UN General Assembly's special session on 
disarmament in May 1978. Soon after, he had a memorandum circulated to all CSCE states. Western allies and neutral countries were lukewarm about the proposal, while the Soviets resolutely rejected it. In the course of the following months, the French diplomacy worked through bilateral relations to promote the CDE idea. Eventually, the French agreed to explain their proposal to the NATO Council, at a special meeting convened on 9 November $1978 .{ }^{35}$ The French representative gave a thorough presentation, and did not shy away from questions. All delegates expressed satisfaction at France's decision to take an active role in the disarmament sphere, and declared their intention to study the proposal farther. ${ }^{36}$ While in the special meeting the emphasis had been on security, at the next NATO Council ministerial meeting in December, Foreign Minister Jean François-Poncet made explicit the détente rationale underpinning the proposal. ${ }^{37}$

President Giscard also briefly expressed the CDE idea at the secret Western Four-Power summit in Guadalupe on 5-6 January 1979, where leaders 'engage[d] in an important exchange of their stillevolving personal viewpoints' on nuclear weapons negotiations, NATO strategy, and European security issues. ${ }^{38}$ British Prime Minister James Callaghan showed perplexity for a conference involving thirty-five states, and concern that a CDE would sharply diminish any hope of reaching an agreement in the MBFR talks. US President Carter questioned whether the French proposal was cosmetic or really aimed at achieving disarmament. West German Chancellor Helmut Schmidt, on the contrary, came out strongly in support of Giscard, praising the French intention to return to multilateral discussions on disarmament. ${ }^{39}$ The CDE, however, was not a matter for the informal and frank discussions that summitry embodied at the time. ${ }^{40}$

The French government, unwilling to lose control on its idea and to see it turned into a bloc-to-bloc tool, delayed detailed discussions within NATO until late 1979. Nonetheless, the French delegation to NATO would continue to give the Council progress reports on the initiative and listen to Allies' comments. ${ }^{41}$ By contrast, it immediately started consultations with EC partners in EPC. ${ }^{42}$ All partners demanded that a link should be established between the CDE and the CSCE, while the 
French proposal at the time envisaged gathering the same participants but in a parallel ad hoc framework. The British underlined the need for such a link even during Anglo-French politicomilitary talks. ${ }^{43}$ The idea was that the socialist bloc's well-known interest in 'military détente' and disarmament offered a leverage to put pressure on their regimes to apply Final Act provisions and adopt new engagements in the field of human contacts/rights. On the contrary, the pursuit of military détente in a forum completely detached from the CSCE process would severely weaken the latter and deprive the West of one of the few valid tools to gradually change socialist regimes. Interestingly, this concern had been first expressed in the above-mentioned NATO special meeting by several diplomats; the Canadian delegate, in particular, had wondered whether it might be worth presenting the proposal for examination at the next CSCE meeting in Madrid, but the French representative had decisively excluded this option. ${ }^{44}$ The idea was voiced in NATO, but EPC made it its own and changed the French attitude. The CDE proposal entered the 'report on the strategy of the Nine before and during the CSCE meeting' prepared by the EPC's CSCE working group; the report was submitted to the Political Committee for discussion, and eventually entered the agenda of the EPC ministerial meeting of November $1979 .{ }^{45}$ The latter fully endorsed the CDE idea and made it an official objective for the next CSCE follow-up meeting. It is noteworthy that the ministerial communiqué presented the CDE as the Nine's approach, and only at the end did it refer to taking into account 'the various considerations which inspired the proposals made by France in May 1978'. Changes had indeed occurred. In the public statement the EC foreign ministers also listed the key CDE's features on which they had agreed:

'meaningful confidence-building measures in the military field. These should be verifiable, applicable to the European continent as a whole and such that, by contributing to the improvement of the security of States, they will create conditions leading later to a process of arms control and reduction within the same geographical framework. ${ }^{46}$ 
Studying the origins of the CDE proposal thus shows that its main features were not determined by the NATO allies in Ankara in June 1980, as argued by scholar John Freeman, ${ }^{47}$ but were rather discussed and agreed upon by the EC governments in EPC meetings in the first instance.

Furthermore, NATO's support of the CDE proposal did not rule out EPC engagement. Although detailed discussion of possible measures, which unfolded from early 1980 onwards, took place largely in NATO committees, ${ }^{48}$ EPC continued its work. Irish neutrality could theoretically serve as an explanation, since the republic was a member of EPC but not of NATO. Still, it does not provide an adequate justification; the Irish could have given 'external' support to a 'NATO' proposal in Madrid negotiations, just as other like-minded CSCE participating states. The EC governments' choice not to delegate to NATO was rooted in their willingness to keep control of the pursuit of such an important goal. As will be demonstrated below, the EC member states were first of all motivated by the determination to preserve détente in Europe and secondly concerned about domestic opinion's attitude towards pacifism. In addition, they all acknowledged the existence of deep-seated differences with Washington in relation to both the conduct of East-West relations and the meaning of détente. Even the new British government led by Margaret Thatcher since May 1979, though adopting a vigorous anti-communist rhetoric and increasing the defence budget, unambiguously stated its intention to "persevere without respite in attempts to improve relations between East and West', and considered defence and détente as 'inseparable'. ${ }^{49}$ It also regarded the CSCE, in particular, as an important and useful forum for East-West dialogue'. 50

The Soviet invasion of Afghanistan on 26 December 1979 reinforced the EC governments' belief in their approach to European relations. The invasion proved the Kremlin's striking ability to mobilise troops of more than 100,000 soldiers within very short time for use at the border with the Asian country; it could do the same for use at the European border. Initiatives aimed at defusing tension and preserving détente, namely the $\mathrm{CDE}$ and the $\mathrm{CSCE}$, became even more important. All EC states' representatives explicitly expressed this view at the NATO Council meeting discussing the 
Allies' CSCE posture after the Afghan crisis. The representatives of Italy and Denmark affirmed their governments' intention to continue and, if possible, consolidate the détente process, and hence to strengthen the viability of the CSCE as a framework for contacts and negotiations between East and West. The German added that it was not in the West's interest to add to the crisis potential in Europe. The Belgian and the French diplomats pointed out that the CSCE provided the West with useful tools to influence Soviet policy in the political security, economic and humanitarian fields. All refused to turn the Madrid meeting in a forum for polemics. ${ }^{51}$

The view was very different in North America. The Canadian representative to NATO questioned the wisdom 'to continue the policy of détente - of which the CSCE was the most institutionalized expression - without coming to an understanding with the East on its application', and suggested that 'it might be more appropriate to demonstrate that détente was not an irreversible process' ${ }^{52}$ The worst reaction came from the Americans. The Carter administration was outraged by the Soviet move and reacted harshly, including sanctions. 1980 was a year of presidential campaign and both candidates self-fashioned themselves as hawks against the Soviets. After the election of Ronald Reagan, whose opposition to the CSCE had been explicit, the EC governments worried that, once in office in January, the new president might withdraw the US delegation from the Madrid meeting, which opened on 11 November 1980. At the following NATO Council ministerial meeting on 12 December, EC foreign ministers Hans-Dietrich Genscher (Germany), Emilio Colombo (Italy), Lord Carrington (Britain), Charles-Ferdinand Nothomb (Belgium), and Christoph van der Klaauw (Netherlands) frankly expressed their support for the CDE proposal and the importance to attain its mandate at the CSCE. Both détente and security were at stake, because the European Soviet territory was, in the words of Genscher, 'the very area where breaks of confidence are possible'. ${ }^{53}$ At the NATO Council meeting of 23 January 1981 convened to discuss the strategy and objectives for the second phase of the Madrid CSCE, the representatives of the EC governments reminded their colleagues that 'the Allies had undertaken to support the French proposal' for a CDE and, in 
the word of Dutch diplomat van Dongen, 'should do their utmost' to support it at Madrid. The Europeans meant to put pressure on the new US administration, which 'had not yet formulated its policy to regard to this proposal' ${ }^{54}$

Reagan did choose continuity, and on 16 February 1981, the head of the US delegation to the CSCE, Max Kampelman, announced that his government supported in principle the CDE proposal. Yet the combination of a strong stance on human rights with Reagan's confrontational rhetoric toward the Soviet Union did not augur well.

Domestic concerns also nourished this urge to decouple Europe from the intensifying superpower discord. No West European governments underestimated the necessity to maintain an adequate level of armed forces and nuclear weapons in place to dissuade Soviet aggression. Good parts of the West European population, though, had grown weary of the arms race; they denounced superpower struggle, actively protested 'nukes', and demanded disarmament accords. In various degrees, all West European governments had to take domestic opinion into account when devising their security and defence policy. This pressure was comparably light in France, where the anti-nuclear sentiment was rather weak and mostly addressed at superpowers' arsenals rather than at national weapons. ${ }^{55}$ The problem was acute for those governments that had accepted to station new US nuclear missiles on their country's territory following NATO's 'dual-track' decision of December 1979 and were facing quite vocal and large anti-nuclear movements. ${ }^{56}$ This was certainly the case of Belgium, Italy, West Germany, and Britain, whose governments did not spare diplomatic efforts to remind the Americans that the other 'track' of the NATO decision concerning disarmament negotiations should also be implemented. ${ }^{57}$ An initiative such as the CDE came in handy.

Finally, EC governments' unitary action in the disarmament field was nourished by their continual discussions on how to forge a European Union. ${ }^{58}$ Whether as part of such an ambitious programme for deeper integration (Belgium, West Germany, and Italy) or simply as a pragmatic step on its own (Britain, Denmark, and Ireland), the idea to improve EPC was shared among the governments of the 
EC member states. In particular, the idea of broadening its scope to security and defence was gaining momentum. National positions varied along the spectrum, from the negative Dutch view that 'real defence issues should be reserved for NATO and excluded from political co-operation,59 to German Foreign Minister Genscher's bold public statement that a common European foreign policy should include co-ordination on defence. Italian Foreign Minister Colombo held very similar views. $^{60}$ The Italo-German interest in pushing the integration process farther was the driver of the Genscher-Colombo initiative the same year, which proposed, among other things, to extend EPC's competence to matters of defence. ${ }^{61}$ However, the Italian government, like most other EC partners, would do nothing that could put the commitment of the US government to European defence at risk, especially at a time of apparent transatlantic strains. ${ }^{62}$ Likewise, the Belgian government cautioned that any broadening of the EPC's scope should avoid weakening the Atlantic Alliance. ${ }^{63}$ The Thatcher government was more open-minded, and Lord Carrington endeavoured throughout his mandate to put EPC on a stronger footing. Although considering defence and disarmament 'primarily the business of NATO', he thought it just natural that EPC should discuss both subjects, as they were part of 'important questions of foreign policy' that EPC had been entitled to discuss since its inception. ${ }^{64} \mathrm{He}$ called for a pragmatic improvement of EPC mechanisms and scope so as to achieve effectiveness and assure rapid reaction, especially in case of international crises. ${ }^{65}$ So it was; on 13 October 1981 the EC foreign ministers approved the London Report on European Political Cooperation. The scope of EPC was not expanded to defence, though; Ireland's insistence on its neutrality requirements prevented such a bold change of mandate. ${ }^{66}$ The London Report only stated that political cooperation included political and economic aspects of security, ${ }^{67}$ hence formalising the existing habit. In doing so, however, it confirmed the policy-making role of EPC, with obvious implications for the consultations in NATO. The same Irish government was clearly committed to strengthening EPC's role; on a number of occasions, it recalled 'that "the Ten" and 
"the West" were not synonymous terms to be used interchangeably', and that 'the Ten should not be treated as a sub-group within a broader western grouping'. ${ }^{68}$

By 1981, the EC governments had consulted closely on aims and tactics for the Madrid CSCE, and were pressing for reaching multilateral agreement on the CDE proposal; they defended it with determination not only against the Soviets but also vis-à-vis the US administration, whose stance at Madrid hardened in response to the worsening of the Polish crisis. ${ }^{69}$ The Thatcher government was particularly supportive of the CDE proposal, as it had grown disillusioned with the MBFR talks. ${ }^{70}$ Lord Carrington was concerned that European public opinion might get the feeling that their governments were putting obstacles to possible discussions on disarmament. ${ }^{71}$ Remarkably, in the early 1981 the CDE was mentioned for the first time in the UK Defence estimates, and referred to by the Defence Secretary John Nott as 'an important proposal concerning security in Europe'.72

The Soviets had accepted the CDE proposal as a basis for discussions. By early 1981, they had agreed in principle that CDE would apply to the whole European part of the Soviet Union, but had requested that the West would extend the confidence zone accordingly. However, provisos remained unexplained. On 31 March 1981 the delegations of neutral and non-aligned states tabled a draft concluding document that, among other things, proposed the extension of the area of application of the future CDE to 'adjoining sea and air space' of the participating countries. The Western delegations were unhappy with the draft. The NATO Council ministerial meeting of 29 April agreed that NATO experts should elaborate a counterproposal for a formula on the CDE's geographical area of application. ${ }^{73}$

In mid-July 1981 the NATO Council agreed on such a formula. The EPC Political Committee hoped that this would suffice to clinch agreement on $\mathrm{CDE}$ and enable the Soviets to make progress on all outstanding issues in Madrid. However, the North Americans posed preconditions to Western approval of the CSCE final document. Both the US and the Canadian governments made their consent dependent on the approval of the proposal for an experts' meeting on human rights and of 
certain measures in the humanitarian field (Third Basket). The Canadians were long-time hardliners in this field; Foreign Secretary Mark MacGuigan had given a passionate statement on the subject at the May 1981 NATO ministerial Council in Rome, concluding that 'human rights cannot be sacrificed for the sake of the military aspects of security'. ${ }^{74}$ EC governments had usually been more pragmatic and anyway opposed to experts meetings on these matters, as their volatile nature could not substitute for strong operational language in the CSCE final document; they were certainly not willing to jeopardise the CDE deal for the sake of such an initiative. ${ }^{75}$ The EC governments instructed their delegations in Madrid accordingly, and their stance did not go unnoticed in NATO. In the course of his farewell speech at the end of his service to NATO in 1981, Canadian Counsellor G. J. Smith said he was 'concerned that the strengthening of the political cooperation process of the Community was leading the Ten to give less weight to what took place in the Alliance'. This was in his view 'a regrettable trend and one which he hoped would not develop far' ${ }^{76}$ Five days later, the US administration decided to throw in some weight. Given that the UK held the EC rotating presidency at the time, US Secretary of State Alexander Haig sent a personal letter to Lord Carrington in which he praised cohesion and teamwork on finding a formula for the $\mathrm{CDE}$ area, but pressed hard on giving priority to human rights issues. He unequivocally stated that, as important as the CDE was, the US administration could not agree to it without balancing progress on human rights; accordingly, the action of US ambassador to CSCE, Max Kampelman, who vocally demanded progress on human rights provisions, had his 'strong personal support' ${ }^{77}$

The Soviets rejected the proposed NATO formula for the CDE geographical zone, and delegations in Madrid agreed on a summer recession until late October. As NATO consultations over the recession period did not help to reach agreement on a new NATO formula, the German permanent representative to NATO, Hans-Georg Wieck, gave a working lunch in Brussels on 12 October to discuss pending divergences. EPC political directors, heads of Madrid CSCE delegations, and 
NATO ambassadors from the United States, France, Germany, Italy, and the UK were present. The discussions focused on the two main bones of contention between the Americans and the Europeans, namely the interpretation of the phrase 'adjoining sea and air area' in the area of application for the CDE, and the balance in the CSCE final document. The US permanent representative insisted on specifying that 'adjoining sea' meant territorial waters only, whether the French proposed a 'functional approach' that would allow to include any activity at sea or in the air that was linked with activity on the land in the scope of the CDE measures of notification. As for the second pending question, Kampelman stated that the Americans would not accept a satisfying deal on the CDE if it were not accompanied by satisfactory results on human rights. In response to Kampelman arguing that there would be no balance without adequate progress on the both elements, British Political Director Julian Bullard said that the American approach was paradoxical: even if the West got agreement to a CDE on Western terms, it would still insist on demanding equally important concessions from the Soviets on human rights. In his view, the logic of balance implied that satisfactory results on the CDE should pair with reasonable language on the human right dimension that could be acceptable to the Kremlin. When Kampelman warned that the political situation in Congress should be taken into account, the British delegate urged the Americans 'not to try to solve their domestic political problems by creating a domestic political problem for [the] Europeans'. He also affirmed that he 'hoped the Americans would not try to suggest that a human rights experts' meeting was more important than a CDE, or that if we got what we wanted on CDE, it would be held up until we got agreement on an experts' meeting on human rights'. $^{78}$

The position of the White House on human rights had hardened in parallel with the worsening of the internal situation in Poland, where the conflict between the authorities and the Solidarity movement was starting to escalate. Given the US government's stonewalling attitude, the EPC ministerial meeting of 13 October 1981 - the very next day after NATO working lunch - discussed 
the CDE issue in detail. Lord Carrington stated that 'the CDE was a prize for which the Ten should press hard. It would be some time before the TNF and SALT discussions produced any results and agreement on a CDE could be important for European public opinion. ${ }^{79}$ German Foreign Minister Genscher suggested that unresolved problems of the mandate should be referred to the EPC Political Committee, a proposal to which French Minster Cheysson readily agreed. ${ }^{80}$ This clearly showed that the foreign ministers of the EC's most powerful countries considered EPC coordination very valuable and aimed at presenting a common front vis-à-vis the Americans and in NATO consultations. EPC also forged a common position on the question of 'balance' in the final Madrid document, establishing that the latter should contain a CDE on Western terms and reasonable - not maximalist - language on human dimension. When the CSCE Madrid meeting reconvened on 27 October, the opening statement given on behalf of the EC Ten explicitly stated their 'positive interest' in the initiation of 'the negotiation of an arms control regime of openness concerning the disposition of major military formations throughout Europe.' The statement also conveyed their annoyance at the length of negotiations on the matter, and the intention of concluding 'our much protracted meeting' by the middle of December. Otherwise they might 'regretfully have to draw the necessary conclusions from the continued lack of agreement. ${ }^{81}$

This position had been agreed within EPC only, as a specific tactic of the Ten. There was indeed a clear lack of agreement across the Atlantic on this issue, as the US government maintained that options should be kept open for the moment. When Kampelman called again on the British, the latter explained that 'the Ten were in complete agreement' that they faced a 'political need' to convince the public opinion 'not to flirt with unilateralism', and that this 'was a strong argument for getting something out of Madrid on the CDE. ${ }^{82}$ The Americans complained that 'public discussion of options should be avoided', and made clear that 'they hoped the European Council would go no further than reaffirming its desire to secure a substantial and balanced concluding document by Christmas'. The British government's opinion was very different. It thought that 'the Americans 
[we]re using the need to avoid publicity (on which we can all agree) as a pretext for preventing the Ten taking a clear view now before discussions in NATO'. The UK position was that EPC should not abandon its decision and should give 'a clear lead to delegations by the beginning of December.' The Europeans would 'of course' consult their Allies 'as soon as possible after the [European] Council meeting,. ${ }^{83}$ Coming from Washington's traditionally closest ally, this says much about EC governments' keenness to speak as one and achieve their goals.

Disagreement with the White House on priorities and tactics became even stronger after the Polish crisis reached its climax with the imposition of the martial law in the country on 13 December 1981. Reagan's hardened stance against the Soviet Union, which included sanctions and refusal to continue negotiations, put the CSCE - and the prospects of CDE - in jeopardy. The history of the transatlantic clashes over the Polish crisis has been adequately covered in recent archive-based literature. ${ }^{84}$ It will suffice here to remind that even Thatcher, who enjoyed the closest personal relationship with the US President, was furious at his unilateral action and outraged that sanctions would intentionally hit West European allies' firms. In early November 1982 Reagan yielded and eventually agreed to resume discussions at Madrid; however, he hardened his requests on human rights provisions. In this deeply exacerbated climate, the governments of the EC member states fought even harder to reach an agreement on the CDE proposal. The German government was particularly vocal on this point. In autumn 1982, Genscher authored an article in which he specifically praised the CDE's potential to make the military activities in Europe more transparent and help to dispel the fear of a surprise attack and the danger of unintentional escalation. ${ }^{85}$ During a visit to Washington in April 1983, Chancellor Helmut Kohl stated that Western European governments attached vital importance to reaching agreement on the $\mathrm{CDE} .^{86}$

The EC member states eventually achieved their goal at Madrid. The difficult relationship with the Reagan administration during the last months had put a strain on transatlantic relations, but had strengthened West European cohesion. EPC had proved able to act as a competitor to NATO, 
despite the latter's heavyweight credentials on security issues. As a matter of fact, the EC governments did not just promote and defend the CDE proposal, but also closely concerted common tactics and drafts for the CDE preparatory meeting in Helsinki, which took place from 25 October to 11 November $1983 .{ }^{87}$ The assessment of their performance at this preparatory phase praised EPC's work and emphasised the positive and autonomous role that the Ten collectively were able to play within CSCE-related multilateral fora. ${ }^{88}$

\section{Cooperation as the complementary dimension of EPC-NATO interaction}

Competition between EPC and NATO never ruled out cooperation on matters related to the CDE. This cooperative stance started with the NATO Council final communique of December 1979 endorsing the French idea as 'a basis upon which to continue developing their approach in this field to bring about such a conference' at the forthcoming Madrid CSCE meeting. ${ }^{89}$ Arguably, cooperation between EPC and NATO could work well also without the participation of the United States. The US administration had kept a reserved position, which the closest allies attributed to both latent scepticism about the $\mathrm{CDE}$ and concern that the latter might undermine MBFR negotiations; then the Soviet invasion of Afghanistan strengthened US reserves, which affected the whole CSCE exercise. Soviet and American postures helped to rally the other NATO allies' support to the French proposal. The Portuguese representative said that the events in Afghanistan 'must not cause the basic CSCE objectives, and particularly the quest for détente, to be abandoned'. The Turkish diplomat was even more vocal: the Ankara authorities regarded 'the quest for détente as the essential precondition for security and stability in the world'; maintained that the Madrid meeting would serve a useful purpose; and called the Allies to 'resist the temptation to use Madrid as a means of getting even with the Soviet Union'. He emphasised that his authorities attached the greatest importance to the military aspects of security discussed at Madrid and to the French proposal for a CDE; so did the Norwegian representative. ${ }^{90}$ 
The coordination between NATO and EPC had been a delicate affair since the inception of the latter. The CSCE had been mostly an EPC affair; the cohesion of the EC governments had provided the foundations for the Western positions in the Helsinki CSCE and then at the review meeting in Belgrade in $1977-78 .^{91}$ Non-EC NATO member states had generally accepted this situation, but had shown considerable sensitivity over matters in which the Alliance had a clear interest and which were also subject of concurrent consultation in EPC, such as Afghanistan and preparations for the Madrid CSCE. As already mentioned, most EC governments, while keen to use EPC to elaborate and then assert unitary positions, were also careful to avoid damage to the Alliance. They thus resolved to take the other NATO allies' sensitivities into account. This proved useful for strengthening the CDE proposal, for instance its provisions for the passage from CDE phase 1 on CSBMs to phase 2 on disarmament. In mid-1980 the French still insisted that this should be automatic; several allies, though, were concerned that the Soviet would have no need to agree on substantial results on CSBMs, as they would get anyway to the disarmament phase, which interested them most. The Norwegians put forward the idea that CDE Phase 1 results should be evaluated at the next CSCE follow-up conference after Madrid, and only in the light of that assessment should a final decision be taken on whether to call a CDE Phase II. ${ }^{92}$ Espoused by other delegations in the following months, this idea became part of the CDE proposal - and eventually of the CDE mandate agreed at Madrid.

The pattern of consultation at the Madrid CSCE meeting changed as well in favour of more punctual NATO coordination. The main reason, though, was that military and security questions, where NATO expertise was necessary, had a larger place in the negotiations. Since the start of the Madrid CSCE in autumn 1980, the basic unit of coordination on site was the 'Group of 16' (NATO plus Spain, which was close to become a member), which did not include the Irish. However, continuing the practice established at earlier meetings, the group of the Ten met before the scheduled meetings of the NATO caucus. Consequently, the delegations that belonged to both 
groups spent about four hours a day on Western coordination activities. ${ }^{93}$

Coordination at Madrid allowed, for example, for solid backing to the French proposal both in the security basket negotiations and in the plenary sessions at a time when five proposals on a disarmament conference or military détente had been tabled, respectively from Poland, France, Yugoslavia, Romania and Sweden. The Polish proposal was the least attractive to Western governments, not only because of its imprecision but because it did not appear to require the prospective conference to take place within the CSCE. It evidently was intended to decouple the military aspects of security, which interested the socialist bloc the most, from the other humanitarian and other aspects of the CSCE that were so troublesome to the socialist regimes. NATO members thought that the West should confront Eastern propaganda proposals on 'military détente' with a concrete and ambitious long-term programme for security discussions in Europe. ${ }^{94}$ Their solidarity in backing the French proposal had not been undermined by the 'almost total silence' of the US delegates - in 1980 the Carter administration was not in a position to commit its successor (Reagan's) to supporting the CDE. The Norwegian delegation had been very effective in attacking the Swedish proposal; the Norwegian representative criticised it for failing to grasp the nettle of the geographical parameter (Soviet territory up to the Urals), for bringing nuclear weapons into the picture, which would make things much more complicated, and for not linking phase two of a CDE to approval of phase one's result by the CSCE follow-up meeting. ${ }^{95}$ In substance, the Norwegian diplomats had firmly defended the key parameters of the French CDE proposal.

Caucus meetings of delegations in Madrid were thus a key vector enhancing cooperation between EPC and NATO. Cooperation was also facilitated by structural similarities of the two organisations: the machinery for political consultation was very similar, with the array of working groups feeding into a political committee which then reported to the NATO Council meeting at the level of permanent delegates ('political directors' in EPC), ministers or, occasionally, heads of government. EPC used to meet before and after NATO meetings; this way, EC members' NATO delegations 
were fully informed of EPC discussions, positions, and agreed proposals and equipped to advance them; likewise, detail of NATO discussions fed back into EPC.

The most important factor behind EPC/NATO cooperation, however, was the continuous work of bridge building and persuasion carried out by some European governments towards the US administration. Not only national sources, but also verbatim and summary records of NATO meetings held in NATO Archives give sound evidence of the fact that US stance on East-West relations and human rights were the main source of tensions within the Alliance; the US attitude clearly emerges as the EC governments' point of concern and annoyance in EPC discussions. National archival sources show that several West European representatives strove to reconcile divergences between the US and European governments. The main rationale behind these efforts was that a deep split between the United States and Western Europe would change the Soviet perception of the Atlantic Alliance in a way that could only damage Western Europe's security.

The first to seek cooperation at the transatlantic level on the CDE proposal was the French president. Since the Guadalupe summit, Giscard had showed keen interest in increased coordination between France and NATO, and the US administration was treating the French 'with complaisance'. This friendly attitude went so far that by early 1981 officials in the British Foreign Office had 'the uncomfortable feeling that there is more communication between the Americans and the French about these [defence] problems than between us and the Americans' ${ }^{96}$ The strength of the allies' backing for the CDE proposal in Madrid owed much to the French recognition that they needed the support of both European and Alliance partners if they wanted the CDE proposal to take off.

Indeed, the French idea only became a solid proposal after it had benefited from NATO expertise. In the preparatory phase for the Madrid meeting, the NATO working group quickly became preoccupied with technical considerations of individual measures linked to the CDE; it decided that the UK government should put forward a clear set of objectives which would make it possible to 
construct a coherent set of CSBMs. The British paper, circulated within NATO in March 1980, defined the goals as reducing the risk of surprise attacks, enhancing warning time in periods of tension, and preserving at an adequate level the Alliance's freedom to react to threatening events. The emphasis was deliberately on the military objectives of the CSBMs, as the UK experts agreed with the French view that measures emerging from a CDE should be military significant. The German, Danish, and Norwegian delegates tended to put equal emphasis on the political objectives of increasing openness and mutual confidence. After intensive debate the working group submitted a report to the NATO Council in July 1980. The agreed set of objectives involved compromises on all sides, but the French probably gave in most. This reflected the fact that the original French package showed a considerable ignorance of both allied military practice and the measures put forward by the West in MBFR covering similar activities. The NATO expertise filled this void and made the CDE proposal stronger by conceiving a package of CSBMs that was clearer, simpler, and with more military "bite" than the one originally conceived by the French. ${ }^{97}$

The French also played an important role in October 1981, when, less than a fortnight before the CSCE would reconvene from summer recession, NATO still could not agree on a new formula on CDE area of application pertaining 'adjoining sea'. The Director of Political Affairs at the French Foreign Ministry - Jacques Andréani - sent a message calling for urgent consultations to the opposite numbers in US, British, and German governments, soliciting a common effort 'to reach a common position which could then be presented, with the customary safeguards, to our other partners in the Alliance.' The accompanying text summarised existing divergences and exposed possible options, and was 'intended to expedite progress towards such a solution'. ${ }^{98}$ This cooperative attitude is particularly important given the change at the helm of French politics: Socialist leader François Mitterrand had been elected president of the Republic in May 1981, and the new government counted two communist ministers.

Most of the work aimed at facilitating reconciliation with the US administration was done jointly by 
the French, British, and West German governments, in particular by their foreign ministers. Together, they tried to either bring the US administration to agree on European positions or at least prevent it from being in the way of European goals. This was mainly the case throughout 1981, during the months of arm-twisting on the questions of defining the CDE geographical zone of application, interpreting the 'adjoining sea' phrasing, and deciding the appropriate tactics at the CSCE negotiations. ${ }^{99}$ When agreement could not be reached due to the American unwillingness to yield on the question of territorial waters, the three West European governments coordinated their position. They proposed that all NATO countries' delegations should adopt a 'self-denying ordinance' on not defining the meaning of 'adjoining sea' at the Madrid negotiations, with the aim of projecting Alliance cohesion vis-à-vis the Soviets. ${ }^{100}$ It also occurred that all the NATO members' representatives 'ganged up' - both in NATO and at the CSCE - to put pressure on the Americans, whose unwillingness to abandon their interpretation of the 'adjoining sea' clause eventually annoyed everyone in the Western camp. ${ }^{101}$ The French 'functional approach' of including sea forces linked with operations on the land proved flexible, convincing and safer for NATO security interests, and very likely to meet the acceptance of the other CSCE participants.

The British were much involved in facilitating NATO cohesion and building bridges across the Atlantic, a role they had historically played. Fundamental in this case was their sincere appreciation of the CDE proposal. The FCO's Defence Department considered it 'likely to make a positive contribution to security in Europe, as well as providing valuable political counter to the East's propaganda proposals on military détente'. ${ }^{102}$ The British government firmly maintained that any European disarmament conference should adopt the essential features of the French proposal. Yet, in order to give the CDE chances of success, it was 'important to have US on board', and British representatives promoted these ideas in the many bilateral contacts they had with the Americans on CDE-related issues. ${ }^{103}$ 
Likewise, the German government considered that security questions would represent the central issue in the CSCE process and saw the continued participation of Canada and the United States as an essential element; 'in the field of arms control and disarmament the Soviets should be given no opportunity to create a split between the European and the North American Allies'. ${ }^{104}$ The German government also proposed concrete measures to foster closer cooperation across the Atlantic. Already in 1980 Genscher had suggested to convene informal meetings of the NATO foreign ministers to discuss high politics issues without a set agenda and without the usual array of civil servants. Such meetings were eventually agreed upon, and NATO foreign ministers gathered for the first informal gathering at the beginning of October 1982 in Montreal. ${ }^{105}$ Even before that, the Germans had convened in Bonn a NATO Summit on 9-10 June 1982 to lay the groundwork for an overall Alliance strategy for the 1980s. Within the latter's scope, the Document on Arms Control and Disarmament affirmed that Western proposals offered the possibility of substantial reductions in conventional forces in Europe, as well as of confidence-building measures covering the whole of Europe. ${ }^{106}$ Accordingly, MBFR and CDE were coupled in NATO's overall strategy, signalling that the EPC initiative had become part of the Alliance's set of policies in the field.

Cooperation on the CDE became established by the end of 1983, in view of the actual CDE negotiations due to open in January 1984. NATO foreign ministers reviewed the various proposals that had been developed so far in the field of CSBMs and of certain aspects of security and disarmament. The Final Communique of the North Atlantic Council of December 1983 recognised the $\mathrm{CDE}$ as 'an important part of the CSCE process' and providing 'new possibilities for increasing security throughout Europe'. It announced that the Allies would table 'a comprehensive package of concrete measures', were 'resolved to negotiate actively', and that '[a]s a sign of their determination' [m]inisters would themselves attend the conference. ${ }^{107}$

Seven days in the CDE in Stockholm, NATO countries' delegates jointly tabled a package of six confidence- and security-building measures that eventually came to define the substance of the 
negotiations. These provisions built significantly upon the Helsinki confidence-building measures: they lowered the notification threshold from 25,000 to 6,000 soldiers involved in a manoeuvre; lengthened the period of notice required from twenty-one to forty-five days; provided for mandatory invitation of observers; and prescribed verification by on-site inspection. ${ }^{108}$ The NATO package was designed to provide greater transparency in military activities in Europe, reduce the chances of miscalculation, and hence build confidence and enhance stability.

At the CDE, NATO was the natural forum for coordination, since military expertise and the advice of military authorities and experts was paramount. The nature of the CDE negotiations meant that EPC played a less important role than at other CSCE meetings. EC governments continued to discuss CDE-related questions in EPC, primarily in the broader political context of East-West relations and with regard to the links between the CDE and the other elements of the CSCE process. At the same time, they valued cooperation within NATO as an essential asset to achieve results in the CDE negotiations.

\section{Conclusions}

The analysis of the debates about the CDE initiative has shed new light on the relations between EPC and NATO in the late 1970s and early 1980s in the field of East-West relations, particularly on its military security aspects. It has demonstrated that the CDE proposal and its main features had clear origins in the EPC framework, that NATO followed suit to endorse the proposal and provided the expertise necessary to flesh it out and integrate it with NATO's overall military strategy. It has also showed that NATO endorsement did not rule out EPC engagement. Quite the contrary, EPC remained the most committed actor sponsoring the CDE proposal at the Madrid CSCE meeting.

Overall, this article has evidenced clear patterns of competition and cooperation between EPC and NATO. Present since EPC's inception in 1970, both forms of interactions became more substantial 
and visible a decade later. A certain degree of competition characterised the relationship between NATO and EPC since the latter's early days, as both organisations engaged in preparing common positions and proposals for the Helsinki CSCE. Moreover, the heads of state and government of the EC member states had initiated EPC to try to speak with a single voice in the realm of foreign policy, and never excluded that EPC could discuss security matters - though strictly military security and defence were carefully avoided.

The competitive relationship between EPC and NATO intensified in the late 1970s and early 1980s, when, following a raise of Cold War tensions, EPC started to discuss the military security aspects of East-West relations more regularly and thoroughly. Competition deepened when EPC took the initiative in defining a concrete approach to disarmament policies for Europe, namely the CDE idea. In so doing, the governments of the EC member states consciously pushed EPC to venture into NATO's domain. They were motivated by the willingness to preserve détente in Europe, which they conceived as a process aimed at gradually overcoming the Cold War order, from the superpowers' renewed confrontation; the concern with public opinion's proclivity to neutralism; and the willingness to use the strength of the group (the EC-Ten) to avoid being marginalised as individual medium and small powers. Moreover, the EC governments' resolve was continually nourished by growing mistrust towards the US administrations, annoyance at the latter's increasing unilateralism in East-West matters, and awareness of divergent interests across the Atlantic. The main trigger for competition between EPC and NATO thus lay in the complicated relationship between the governments of the EC member states and the United States administrations when security, cooperation, and détente in Europe were at stake. It is possible to affirm that all EC governments were responsible for competition dynamics, as they all shared the above-mentioned rationales. It is noteworthy, though, that the Thatcher government was very much part of this cohort, qualifying the commonly projected image of harmonious views between the British prime minister and US President Reagan. 
EPC's competition with NATO is evident not only in EPC taking the initiative in the field of disarmament in Europe, but also in the fact that it led the way at the Madrid CSCE. In particular, tactics and priorities agreed within EPC were rarely altered after NATO consultations, and sometimes applied straight to CSCE negotiations without prior coordination with the other NATO allies.

Cooperation was also present in principle since the beginning, given NATO's competence, which no West European governments questioned, and the dual membership of all EC member states but Ireland in EPC and NATO. However, cooperation really took off after EPC had elaborated a clear draft mandate for the CDE and CSCE negotiations had started. At the Madrid CSCE meeting the NATO caucus was much more active than the EPC group; this was partly because EC governments took into account the resentment of the other NATO members at being presented with detailed positions already agreed among the Ten, and primarily because NATO expertise was necessary in negotiations on military and security questions. However, a fundamental driver behind EPC's effort at promoting cooperation within NATO, which all governments shared, was the need to preserve Atlantic solidarity and project Western cohesion at times of strained transatlantic relations and high East-West tensions. A weakened NATO would serve neither West European security nor détente, which were top priorities of EC governments' foreign policy. Some governments stand out for their efforts to build bridges within NATO and towards the US administration in particular: the British, the German, and most remarkably, the French. Not only did they act via bilateral channels, they also coordinated their action in secret tripartite consultations. Cooperation within NATO was paramount in drafting military measures proposals, and in actual CDE negotiations later on.

Finally, a stronger EPC had also a positive effect on NATO's cohesion and own consultations mechanisms, as NATO came to emulate EPC structures and practices. Moreover, NATO ultimately embraced EPC's disarmament initiative as an Alliance flag policy; proposed in July 1987 at the Vienna follow-up meeting, this became eventually the Treaty on Conventional Forces in Europe 
(CFE), signed in November 1990.

Finally, the CDE case shows that the Cold War continued to push EC governments towards broader and more effective foreign policy coordination in EPC. It thus confirms recent Cold War historiography's argument that the EC member states collectively (whether as supranational EC or by means of EPC) played a key role in shaping East-West relations since the early 1970s. This article also adds to recent European integration historiography that argues in favour of considering the 1970 s and early 1980 s as a constructive period of the integration process: it contributes to showing that non-supranational forms of close cooperation flourished between EC governments, and enhanced their international visibility as a close-knit group ("the Ten"). Ultimately, this nourished third countries' perception of an EC's international role, as the subtleties of EPC/EC relationship were neither evident nor explained to them. As a matter of fact, Cheysson's speech at the CDE opening session referred to 'the ten members of the European Community', not to EPC.

\section{Acknowledgements}

I wish to thank Kiran K. Patel and Wolfram Kaiser for inviting me to contribute an article in this special issue and for their comments on earlier drafts. I am grateful to the anonymous reviewers for their thought-provoking remarks, which helped me strengthen the article in terms of its contribution to historiography. Finally, my heartfelt thanks go to Nicholas Nguyen, Johannes Geurts, and Nicholas Roche at NATO Archives for their assistance and for welcoming me so nicely at very short notice. 


\title{
Bibliography
}

\author{
Archival Material \\ Archive of European Integration, University of Pittsburgh (AEI) \\ Archives du Ministère des Affaires Étrangères, Paris (AMAE) \\ Historical Archives of the European Union, Florence (HAEU) \\ NATO Archives, Brussels (NATO Arch) \\ The National Archives of the UK, London (TNA)
}

\section{Online Archival Sources}

Report on Future Tasks of the Alliance (annexed to Final Communiqué), Brussels, $13^{\text {th }}-14^{\text {th }}$ December 1967. http://www.nato.int/cps/en/natolive/official texts 26700.htm

Mutual And Balanced Force Reductions. Declaration adopted by Foreign Ministers and Representatives of Countries participating in the NATO Defence Program', Reykjavik, $24^{\text {th }}-25^{\text {th }}$ June 1968. http://www.nato.int/docu/comm/49-95/c680624b.htm

Declaration of the North Atlantic Council on European Security, Brussels, $4^{\text {th }}-5^{\text {th }}$ December 1969. http://www.nato.int/docu/comm/49-95/c691204b.htm

Aide-mémoire from the French Government to the other 14 NATO countries, 11 March 1966. http://www.cvce.eu/obj/aide memoire from the french government 11 march_1966-en690b3dd8-ee03-4737-85a4-d5b839b2e0dc.html.

North Atlantic Council Communiqué, Brussels, December 9-10, 1971. http://www.nato.int/cps/en/natohq/official texts 26812.htm?selectedLocale=en

North Atlantic Council, Brussels 13th-14th December 1979, Final communiqué. http://www.nato.int/docu/comm/49-95/c791213a.htm

North Atlantic Council, Ankara 25th-26th June 1980, Final Communiqué. http://www.nato.int/docu/comm/49-95/c800625a.htm

Final Communiqué of North Atlantic Council Ministerial Session at Brussels on 13th and 14th December 1979. http://www.nato.int/docu/comm/49-95/c791213a.htm

Final Communiqué of North Atlantic Council Ministerial Session at Ankara on the 25th and 26th June 1980. http://www.nato.int/docu/comm/49-95/c800625a.htm

NATO, 'Document on Arms Control and Disarmament', 10 June 1982. http://www.nato.int/cps/en/natohq/official texts 23156.htm?selectedLocale=en

URL: http://mc.manuscriptcentral.com/cerh Email: 
Final Communiqué of the North Atlantic Council met in Ministerial Session at Brussels on 8th and 9th December 1983. http://www.nato.int/cps/en/natohq/official texts_23215.htm?selectedLocale=en

Final Recommendations of the Helsinki Consultations, Helsinki 1973. http://www.osce.org/mc/40213.

Final Act. www.osce.org/node/39501.

HC Deb 18 May 1979 vol 967 cc555-657, Hansard, UK Parliament. http://hansard.millbanksystems.com/commons/1979/may/18/foreign-affairs

HL Deb 16 January 1979 vol 397 cc865-76. Hansard, UK Parliament. http://hansard.millbanksystems.com/lords/1979/jan/16/the-guadeloupe-summit

Tindemans, 'European Union. Report by Mr. Leo Tindemans, Prime Minister of Belgium, to the European Council', Bulletin of the European Communities, Supplement 1/76, AEI, $\underline{\mathrm{http}: / / \text { aei.pitt.edu/id/eprint/942 }}$

European Commission, 'Report on European Union. COM (75) 400 final, 25 June 1975', Bulletin of the European Communities, Supplement 5/75, AEI. http://aei.pitt.edu/id/eprint/1761

Reports on European Union. European Parliament. Court of Justice. Economic and Social Committee', Bulletin of the European Communities, Supplement 9/75, AEI. http://aei.pitt.edu/id/eprint/5590

\section{Grey Literature}

Report on European Union from the Ministers of Foreign Affairs to the European Council. Bulletin of the European Communities, Supplement 4/80, Luxembourg: Office for Official Publications of the European Communities, 1981.

Report on European Union from the Ministers of Foreign Affairs to the European Council. Bulletin of the European Communities, Supplement 3/81, Luxembourg: Office for Official Publications of the European Communities, 1982.

Report on European Union from the Ministers of Foreign Affairs to the European Council. Bulletin of the European Communities, Supplement 7/1982, Luxembourg: Office for Official Publications of the European Communities, 1983.

Documents on British Policy Overseas, Series III, Volume II, eds. Gill Bennett and Keith A. Hamilton. London. The Stationery Office, 1997.

\section{Secondary Literature}

Allen, David, and Andrin Hauri. 'The Euro-Arab Dialogue, the Venice Declaration, and Beyond: The Limits of a Distinct EC Policy, 1974-89', in European-American Relations and the Middle East: From Suez to Iraq, eds. Daniel Möckli and Victor Mauer. London: Routledge, 2010: 93-107. 
Bilandzic, Vladimir, Dittmar Dahlmann and Milan Kosanovic (eds.). From Helsinki to Belgrade. The First CSCE Follow-up Meeting and the Crisis of Détente. Göttingen: Vandenhoeck \& Ruprecht, 2012.

Bluth, Christoph. 'Détente and Conventional Arms Control: West German Policy Priorities and the Origins of MBFR.' German Politics 8 (1999): 181-206.

Bossuat, Gérard. 'Origins and Development of the External Personality of the European Community', in Experiencing Europe. 50 Years of European Construction 1957-2007, ed. Wilfried Loth. Baden-Baden: Nomos, 2009: 217-254.

Brier, Robert. 'Poland's Solidarity as a Contested Symbol of the Cold War: Transatlantic Debates after the Polish Crisis', in European integration and the Atlantic Community in the 1980s, eds. Kiran K. Patel and Ken Weisbrode. Cambridge: Cambridge University Press, 2013: 83-104.

Dean, Jonathan. 'Military Security in Europe.' Foreign Affairs 66 (Fall, 1987): 22-40.

Deighton, Anne. 'Foreign and Security Policy after the End of the Cold War', in Experiencing Europe. 50 Years of European Construction 1957-2007, ed. Wilfried Loth. Baden-Baden: Nomos, 2009: 255-267.

Deighton, Anne, and Gérard Bossuat (eds.). The EC/EU: a World Security Actor? Paris: Soleb, 2007.

Dijk, Ruud van. "'A Mass Psychosis": The Netherlands and NATO's Dual-Track Decision, 19781979.' Cold War History 12 (2012): 381-405.

Dujardin, Vincent. 'From Helsinki to the Missiles Question: A Minor Role for Small Countries? The case of Belgium (1973-1985)', in The Crisis of Détente in Europe: From Helsinki to Gorbachev 1975-1985, ed. Leopoldo Nuti. Abingdon and New York: Routledge, 2008: 72-85.

Ferrari, Lorenzo. Sometimes Speaking with a Single Voice: The European Community as an International Actor, 1969-1979. Brussels: Peter Lang, 2016.

Fisher, Thomas. Neutral Power in the CSCE: The N+N States and the Making of the Helsinki Accords 1975. Baden-Baden: Nomos, 2009.

Freeman, John. Security and the CSCE Process: The Stockholm Conference and Beyond. London: Macmillan, 1991.

Gala, Marilena. 'From INF to SDI: How Helsinki Reshaped the Transatlantic Dimension of European security', in The Crisis of Détente in Europe: From Helsinki to Gorbachev 1975-1985, ed. Leopoldo Nuti. Abingdon and New York: Routledge, 2008: 111-123.

Geiger, Tim. 'Die Regierung Schmidt-Genscher und der NATO-Doppelbeschluss', in Zweiter Kalter Krieg und Friedensbewegung. Der NATO-Doppelbeschluss in deutsch-deutscher und internationaler Perspektive, eds. Philipp Gassert, Tim Geiger, and Hermann Wentker. Munich: Oldenbourg, 2011: 95-120. 
Genscher, Hans-Dietrich. 'Toward an Overall Western Strategy for Peace, Freedom and Progress.' Foreign Affairs 61 (Fall 1982): 42-66.

Ghebali, Victor-Yves. Confidence-building Measures Within the CSCE Process: Paragraph-byparagraph Analysis of the Helsinki and Stockholm Régimes. New York: UNIDIR Research Paper, 1989.

Guasconi, Eleonora. 'Public Opinion and the Euromissile Crisis', in The Euromissile Crisis and the End of the Cold War, eds. Leopoldo Nuti, Frédéric Bozo, Marie-Pierre Rey, and Bernd Rother. Washington, D.C.: Woodrow Wilson Center Press, 2015: 271-290.

Heyde, Veronika. 'Multilaterale Konferenzdiplomatie unter nationaler Flagge. Die KSZE-Politik von Präsident Giscard d'Estaing 1974 1978', in Der KSZE-Prozess Vom Kalten Krieg zu einem neuen Europa 1975 bis 1990, eds. Helmut Altrichter and Hermann Wentker. Munich: Oldenbourg, 2011: 29-40.

Heyde, Veronika. 'Nicht nur Entspannung und Menschenrechte Die Entdeckung von Abrüstung und Rüstungskontrolle durch die französische KSZE-Politik', in Die KSZE im Ost-West-Konflikt Internationale Politik und gesellschaftliche Transformation 1975-1990, eds. Matthias Peter, Hermann Wentker. Munich: Oldenbourg, 2012: 83-98.

Loth, Wilfried. Building Europe: A History of European Unification. Berlin: de Gruyter, 2015.

Möckli, Daniel. European Foreign Policy During the Cold War: Heath, Brandt, Pompidou and the Dream of Political Unity. London: LB. Tauris, 2008.

Möckli, Daniel. 'The EC-Nine and Transatlantic Conflict During the October War and the Oil Crisis, 1973-4', in European-American Relations and the Middle East: From Suez to Iraq, eds. Daniel Möckli, and Victor Mauer. London: Routledge, 2010: 77-92.

Mourlon-Druol, Emmanuel. 'More than a Prestigious Spokesperson: the Role of Summits/the European Council in European Political Cooperation (EPC), 1969-1981', in The Commanding Heights of the European Union. The European Council: institution, actors, resources, eds. François Foret and Yann-Sven Rittelmeyer. London: Routledge, 2013: 43-52.

Mourlon-Druol, Emmanuel, and Federico Romero (eds.) International Summitry and Global Governance. The Rise of the G-7 and the European Council, 1974-1991. London and New York: Routledge, 2014.

Nehring, Holger. 'The Last Battle of the Cold War: Peace Movements and German Politics in the 1980s', in The Euromissile Crisis and the End of the Cold War, eds. Leopoldo Nuti, Frédéric Bozo, Marie-Pierre Rey, and Bernd Rother. Washington, D.C.: Woodrow Wilson Center Press, 2015: 309-330.

Nuti, Leopoldo. 'The Origins of the 1979 Dual Track Decision - a Survey', in The Crisis of Détente in Europe: From Helsinki to Gorbachev 1975-1985, ed. Leopoldo Nuti. Abingdon and New York: Routledge, 2008: $57-71$.

Park, Bill. 'NATO Summits', in Diplomacy at the Highest Level: The Evolution of International 
Summitry, ed. David H. Dunn. Basingstoke and London: Macmillan, 1996: 88-105.

Patel, Kiran Klaus, 'Provincialising European Union: Co-operation and Integration in Europe in a Historical Perspective.' Contemporary European History 22 (2013): 649-673.

Pijpers, Alfred, Elfriede Regelsberger, and Wolfgang Wessels (eds.). European Political Cooperation in the 1980s. Dordrecht: Martinus Nijhoff, 1988.

Romano, Angela. 'Western Europe's Self-Assertion Towards the Superpowers: the CSCE Chance and its Aftermaths', in The EC/EU: a World Security Actor?, eds. Anne Deighton and Gérard Bossuat. Paris: Soleb, 2007: 152-169.

Romano, Angela. From Détente in Europe to European Détente. How the West Shaped the Helsinki CSCE. Brussels: Peter Lang, 2009.

Romano, Angela. 'A Single European Voice Can Speak Louder to the World: Rationales, Ways and Means of EPC in the CSCE experience', in The Road to a United Europe. Interpretations of the Process of European Integration, ed. Morten Rasmussen and Ann-Kristina Knudsen. Bruxelles: Peter Lang, 2009: 257-270.

Romano, Angela. 'The Main Task of the European Political Cooperation: Fostering Détente in Europe', in Perforating the Iron Curtain: European Détente, Transatlantic Relations, and the Cold War, 1965-1985, eds. Poul Villaume and Odd Arne Westad. Copenhagen: Museum Tusculanum, 2010: 123-141.

Romano, Angela. 'The European Community and the Belgrade CSCE', in From Helsinki to Belgrade. The First CSCE Follow-up Meeting and the Crisis of Détente, eds. Vladimir Bilandzic, Ditter Dahlmann and Milan Kosanovic (eds.). Göttingen: Vandenhoeck \& Ruprecht, 2012: 205224.

Romano, Angela. 'More Cohesive, Still Divergent: Western Europe, the US, and the Madrid CSCE Follow-Up Meeting', in European integration and the Atlantic Community in the 1980s, eds. Kiran K. Patel and Ken Weisbrode. Cambridge: Cambridge University Press, 2013: 39-58.

Romano, Angela. 'G-7s, European Councils and East-West Economic Relations, 1975-1982', in International Summitry and Global Governance. The Rise of the G-7 and the European Council, 1974-1991, eds. Emmanuel Mourlon-Druol and Federico Romero. London and New York:

Routledge, 2014: 198-222.

Rother, Bernd. 'Family Row: The Dual-Track Decision and Its Consequences for European Social Democratic Cooperation', in The Euromissile Crisis and the End of the Cold War, eds. Leopoldo Nuti, Frédéric Bozo, Marie-Pierre Rey, and Bernd Rother. Washington, D.C.: Woodrow Wilson Center Press, 2015: 331-347.

Selvage, Douglas. 'The Politics of the Lesser Evil: the West, the Polish Crisis, and the CSCE Review Conference in Madrid, 1981-83', in The Crisis of Détente in Europe: From Helsinki to Gorbachev 1975-1985, ed. Leopoldo Nuti. London: Routledge, 2009: 41-54.

Spohr, Kristina. 'Conflict and Cooperation in Intra-Alliance Nuclear Politics: Western Europe, the United States, and the Genesis of NATO's Dual-Track Decision, 1977-1979.' Journal of Cold War 
Studies 13:2 (2011): 39-89.

Spohr, Kristina. 'Helmut Schmidt and the Shaping of Western Security in the Late 1970s: the Guadeloupe Summit of 1979.' The International History Review, 37:1 (2015): 167-192.

Spohr, Kristina, and David Reynolds (eds.) Transcending the Cold War: Summits, Statecraft, and the Dissolution of Bipolarity in Europe, 1970-1990. Oxford: OUP, 2016.

Wallace, William. 'European Political Co-Operation: A New Form of Diplomacy?' Irish Studies in International Affairs 1 (1984): 3-14. 
${ }^{1}$ Paris COREU (suite), 11 janvier 1984, 5020, AMAE (translated from French by the author).

${ }^{2}$ For an overview: Deighton, 'Foreign and Security Policy after the End of the Cold War', 255-267.

A just-published work briefly considering 1973-74 (failed) attempts to include defence in EC's international activity confirms the same argument: Ferrari, Sometimes Speaking with a Single Voice, $66-70$.

${ }^{3}$ Deighton and Bossuat, The EC/EUs: a World Security Actor?; Bossuat, 'Origins and

Development'; Möckli, European Foreign Policy. Specifically on the role of EC/EPC in the CSCE:

Romano, From Détente in Europe to European Détente; on EPC and Middle East: Möckli, 'The

EC-Nine and Transatlantic Conflict'; Allen and Hauri, 'The Euro-Arab Dialogue, the Venice

Declaration'.

${ }^{4}$ On such inter-organisational links: Patel, 'Provincialising European Union'.

${ }^{5}$ Nuti et al., The Euromissile Crisis and the End of the Cold War; Nuti, 'The Origins of the 1979

Dual Track Decision - a Survey'; Dujardin, 'From Helsinki to the Missiles Question“; Spohr,

'Conflict and Cooperation in Intra-Alliance Nuclear Politics'; Spohr, 'Helmut Schmidt and the Shaping of Western Security in the Late 1970s'.

${ }^{6}$ Park, 'NATO Summits', 90.

${ }^{7}$ In 1952 Greece and Turkey became members.

${ }^{8}$ Wallace, 'European Political Co-Operation', 9.

${ }^{9}$ The Single European Act of 1986 gave a treaty base to EPC.

10 'Report on Future Tasks of the Alliance' annexed to Final Communiqué, Brussels, $13^{\text {th }}-14^{\text {th }}$ December 1967, par. 13, NATO. 
11 'Mutual And Balanced Force Reductions. Declaration adopted by Foreign Ministers and Representatives of Countries participating in the NATO Defence Program', Reykjavik, $24^{\text {th }}-25^{\text {th }}$ June 1968.

12 'Aide-mémoire from the French Government to the other 14 NATO countries', 11 March 1966. French forces' reintegration into NATO's military command took place in 2009; it did not entail integrating the Force de Frappe.

13 'Declaration of the North Atlantic Council on European Security, Brussels, $4^{\text {th }}-5^{\text {th }}$ December 1969, par. 14. Accessed at http://www.nato.int/docu/comm/49-95/c691204b.htm

${ }^{14}$ CC24(1970), 27 May 1970, CAB 128/45, TNA.

${ }^{15}$ Minute from Tickell, FCO, 23 May 1972, Doc. no. 9, DBPO.

${ }^{16}$ Brief by FCO, 2 April 1971, CAB 133/416, TNA; Note, MAE - Sous-Direction Europe Orientale, 1 juillet 1972, 2924, AMAE. See also Bluth, 'Détente and Conventional Arms Control'.

${ }^{17}$ Letter UK Embassy Stockholm to Tickell (WOD), 26 May 1972, FCO 28/1690, TNA.

${ }^{18}$ Letter Ministry of Defence to PM Heath, 29 November 1972, PREM 15/1279, TNA.

${ }^{19}$ For detail see Romano, 'Western Europe's Self-Assertion Towards the Superpowers'; and Romano, 'The Main Task of the European Political Cooperation'. Candidate states were associated to EPC beforehand: the UK since February 1972, Ireland and Denmark in May of the same year. They joined the EC on 1 January 1973.

${ }^{20}$ Fisher, Neutral Power in the CSCE.

${ }^{21}$ For a detailed analysis, see Ghebali, Confidence-building Measures Within the CSCE Process.

${ }^{22}$ Dean, 'Military Security in Europe', 30.

${ }^{23}$ Final Act, 'Document on confidence-building measures and certain aspects of security and disarmament', 10.

${ }^{24}$ Note by the Secretary-General, 'Confidence-building measures: past and present', 22 June 1979, C-M(79)46, NATO Arch. 
${ }^{25}$ Rose (UKDEL NATO) to Lord Carrington (FM), 22 January 1981, FCO 28/4671, TNA.

${ }^{26}$ CSCE (80) 2/CP/, 14 mars 1980, 4211 bis, Communautés Européennes 1976-80, AMAE.

${ }^{27}$ Final communiqué, North Atlantic Council, Brussels 13 ${ }^{\text {th }}-14$ th December 1979, par. 8; and Final Communiqué, North Atlantic Council, Ankara 25th-26th June 1980, par. 8.

${ }^{28}$ Heyde, 'Multilaterale Konferenzdiplomatie unter nationaler Flagge’, 39.

${ }^{29}$ Heyde, 'Nicht nur Entspannung und Menschenrechte', 91-92.

${ }^{30}$ Dispatch, Rose (UKDEL NATO) to Gillmore (Defence Dept), 23 January 1981, FCO 28/4671, TNA.

${ }^{31}$ See Romano, 'The European Community and the Belgrade CSCE'.

${ }^{32}$ Romano, 'A Single European Voice Can Speak Louder'.

${ }^{33}$ Romano, 'G-7s, European Councils and East-West Economic Relations; Mourlon-Druol, 'More than a Prestigious Spokesperson'.

${ }^{34}$ Carrington (FM) to Deakins, MP, December 1980, FCO 98/959, TNA.

35 'Summary record of a meeting of the Council held at the NATO HQ, Brussels, on Wednesday $27^{\text {th }}$ September 1978', C-R(78)32, NATO Arch.

36 'Summary record of a meeting of the Council held at the NATO HQ, Brussels, on $9^{\text {th }}$ November 1978', C-R(78)39, NATO Arch.

37 'Summary record of a meeting of the Council in Ministerial Session held at NATO HQ, Brussels, on Friday, $7^{\text {th }}$ December 1978', C-R(78)47 - PART 1, NATO Arch.

${ }^{38}$ Spohr, 'Helmut Schmidt and the Shaping of Western Security in the Late 1970s', 174. This article does not even mention the CDE.

${ }^{39}$ Conclusions of Cabinet meeting, 11 January 1979, CAB/128/65/1, TNA. CDE was merely mentioned in 'The Guadeloupe Summit', HL Deb 16 January 1979, House of Lords.

${ }^{40}$ See Mourlon-Druol and Romero, International Summitry and Global Governance; and Spohr and Reynolds, Transcending the Cold War. 
41 'Summary Record of a Restricted Meeting of the Council in Ministerial Session on Thursday $7^{\text {th }}$ December 1978', PR(78)56-BIL; 'Summary Record of a meeting of the Council held at the NATO HQ, Brussels on Tuesday, 8th May 1972', C-R(79)18; 'XXVIIIth Semi-Annual Meeting of the Political Committee with Disarmament Experts', $15^{\text {th }}$ November 1979, PO/79/117, NATO Arch. Also: Dispatch Rose (UKDEL NATO) to Gillmore (Defence Dept), 23 January 1981, FCO 28/4671, TNA.

${ }^{42}$ Brief, Europan Integration Dept (External), 26 Feb 1979, FCO 98/637, TNA; Paris COREU to All COREU, 21 April 1979, FCO 98/637, TNA.

${ }^{43}$ Dispatch, Rose (UKDEL NATO) to Gillmore (Defence Dept), 23 January 1981, FCO 28/4671, TNA.

44 'Summary record of a meeting of the Council held at the NATO HQ, Brussels, on $9^{\text {th }}$ November 1978', C-R(78)39, NATO Arch.

${ }^{45}$ Dublin COREU to All COREU, 05 September 1979, FCO 98/637, TNA.

${ }^{46}$ European Political Cooperation statements of the Foreign Ministers and other documents 1979, AEI, 80-81.

${ }^{47}$ Freeman, Security and the CSCE Process, 85-87.

${ }^{48}$ Jackson (POCO) to Cooper (ECD external), 10 June 1981, FCO 98/1175.

${ }^{49}$ HC Deb 18 May 1979 vol 967 cc555-657, 2.

${ }^{50}$ FCO Secretary of State to all posts, 7 December 1979, FCO 28/3683, TNA.

51 'Summary Record of a meeting of the Council held at NATO HQ Brussels on Wednesday $28^{\text {th }}$ May 1980', C-R(80)21, NATO Arch.

52 Ibid.

53 'Verbatim Record of the Meeting of the North Atlantic Council in Ministerial session held on Friday $12^{\text {th }}$ Dec 1980 at NATO HQ Brussels', C-VR(80)48 Part 2, NATO Arch. 
54 'Summary Record of a meeting of the Council held at NATO HQ, Brussels on Friday $23^{\text {th }}$ January 1981', C-R(81)3, NATO Arch.

${ }^{55}$ Cooper (POCO Unit, FCO) to FitzHerbert (ECD external), 26 October 1981, FCO 98/1175, TNA.

${ }^{56}$ For detailed analysis see: Dujardin, 'From Helsinki to the Missiles Question“; Dijk, “”A Mass Psychosis"'; Guasconi, 'Public Opinion and the Euromissile Crisis'; Nehring, 'The Last Battle of the Cold War'; Rother, 'Family Row'.

${ }^{57}$ Gala, 'From INF to SDI', 116-118; Geiger, 'Die Regierung Schmidt-Genscher und der NATODoppelbeschluss'.

${ }^{58}$ By 1976 three reports had been circulated for discussions: Tindemans, 'European Union. Report, AEI; European Commission, 'Report on European Union', AEI; EP, 'Reports on European Union', AEI.

${ }^{59}$ Budd (UK Embassy The Hague) to Cooper (POCO Unit, FCO), 13 February 1981, FCO 98/1175, TNA.

${ }^{60}$ EC, PE 71.832/fin, 'Report on European political cooperation and the role of the European Parliament', 30 June 1981, HAEU.

${ }^{61}$ On the Genscher-Colombo initiative see Loth, Building Europe, 264-5.

${ }^{62}$ Tomkys (UK Embassy Rome) to Scott (UKDEL NATO), 24 August 1981, FCO 98/1175, TNA.

${ }^{63}$ Richards to FitzHerbert (ECD external), 21 December 1981, FCO 98/1175, TNA.

${ }^{64}$ Carrington (FM) to Deakins, MP, December 1980, FCO 98/959, TNA.

${ }^{65}$ Note, Secretary of State for Foreign and Commonwealth Affairs, 17 September 1981, CAB/129/213/21; Letter, Carrington (FM) to Prime Minister, 4 June 1981, FCO 98/1175, TNA.

${ }^{66}$ Staples (UK Embassy Dublin) to Newington (Irish Dept., FCO), 20 June 1980, FCO 98/969, TNA.

${ }^{67}$ Note, Secretary of State for Foreign and Commonwealth Affairs, 17 September 1981, 
CAB/129/213/21, TNA.

${ }^{68}$ La Haye COREU to all COREU, 12 May 1981, FCO 98/1179, TNA.

${ }^{69}$ Report on European Union from the Ministers of Foreign Affairs to the European Council, 1981; idem, 1982; idem, 1983.

${ }^{70}$ Ambassade de France, Aout 1981, COM/1/3 1981, 5857, AMAE.

${ }^{71}$ Tel. 20281 de Dufourcq (Londres), 29 mai 1981, COM/1/3 1981, 5857, AMAE.

${ }^{72}$ Note, Secretary of State for Defence, 16 March 1981, CAB/129/211/11, TNA.

${ }^{73}$ Brief no. 8, POCO Unit FCO, 20 May 1981, FCO 98/1179, TNA.

74 'Verbatim Record of the Meeting of the North Atlantic Council in Ministerial session held on Monday $4^{\text {th }}$ May 1981, Rome', C-VR(81)18, NATO Arch.

${ }^{75}$ Brief, POCO Unit FCO, 16 July 1981, FCO 46/2671, TNA.

${ }^{76}$ Alston (UKDEL NATO) to Johnson (EESD, FCO, 15 July 1981, FCO 98/1172, TNA.

${ }^{77}$ Louis (USA Embassy London) to Carrington (FM), 20 July 1981, FCO 46/2671, TNA.

${ }^{78}$ Note for the record, Rose (UKDEL NATO), 12 October 1981, FCO 28/4671, TNA.

${ }^{79}$ Tel. from Carrington (FM), 14 October 1981, FCO 98/1179, TNA.

${ }^{80}$ Ibid.

81 'CSCE, Opening Statement on behalf of the Ten (Madrid, 27 October 1981)', in European

Political Cooperation in the 1980s, ed. Pijpers, Regelsberger, and Wessel: 347-8.

${ }^{82}$ Carrington (FM) to Washington and all EC posts, 15 October 1981, FCO 28/4671, TNA.

${ }^{83}$ Hughes (CSCE Unit) to Broomfield (EESD), 25 November 1981, FCO 98/1179, TNA.

${ }^{84}$ Romano, 'More Cohesive, Still Divergent', 48-52; Brier, 'Poland's Solidarity as a Contested Symbol', 83-104.

${ }^{85}$ Genscher, 'Toward an Overall Western Strategy'.

${ }^{86}$ Selvage, 'The Politics of the Lesser Evil', 46.

${ }^{87}$ Tel. COREU Athènes, 5 décembre 1983, 5020, Communautés Européennes, AMAE. 
${ }^{88}$ Tel. COREU Athènes, 29 novembre 1983, 5021, Communautés Européennes, AMAE.

${ }^{89}$ Final Communiqué of the North Atlantic Council met in Ministerial Session in Brussels, 13th and 14th December 1979, par. 8.

90 'Summary Record of a meeting of the Council held at NATO HQ Brussels on Wednesday $28^{\text {th }}$ May 1980', C-R(80)21, NATO Arch.

${ }^{91}$ Jackson (POCO) to Cooper (ECD external), 10 June 1981, FCO 98/1175, TNA.

92 'Summary Record of a meeting of the Council held at NATO HQ, Brussels on Thursday $7^{\text {th }}$ July 1980', C-R(80)27, NATO Arch.

${ }^{93}$ Jackson (POCO) to Cooper (ECD external), 10 June 1981, FCO 98/1175, TNA.

${ }^{94}$ Dispatch, Rose (UKDEL NATO) to Gillmore (Defence Dept), 23 January 1981, FCO 28/4671, TNA.

${ }^{95}$ Hulse (UKDEL CSCE Madrid) to Pearce (Defence Dept), 9 February 1981, FCO 28/4671, TNA.

${ }^{96}$ Gladstone (WED) to Gillmore (Defence Dept), 31 March 1981, FCO 98/1175, TNA.

${ }^{97}$ Dispatch, Rose (UKDEL NATO) to Gillmore (Defence Dept), 23 January 1981, FCO 28/4671, TNA.

${ }^{98}$ Message from Andreani, 20 October 1981, FCO 28/4671, TNA.

${ }^{99}$ Carrington (FM) to FCO, 9 April 1981, FCO 98/1179; Carrington (FM) to Bonn and Paris, 5 July 1981, FCO 46/2671; Carrington (FM) to immediate Bonn, 20 October 1981, FCO 28/4671, TNA. ${ }^{100}$ Carrington (FM) to immediate Paris and Bonn, 26 October 1981, FCO 28/4671, TNA.

${ }^{101}$ Hulse (UKDEL Madrid CSCE) to Pearce (Defence Dept.), 7 July 1981, FCO 46/2671, TNA.

102 Gillmore (Defence Dept) to Rose (UKDEL NATO), 13 February 1981, FCO 28/4671, TNA. ${ }^{103}$ FCO, Brief, 12 July 1981, FCO 46/2671, TNA.

104 'Summary Record of a meeting of the Council held at NATO HQ, Brussels on Thursday $7^{\text {th }}$ July 1980’, C-R(80)27, NATO Arch.

${ }^{105}$ Genscher, 'Toward an Overall Western Strategy', 64. 
${ }^{106}$ NATO, 'Document on Arms Control and Disarmament', 10 Jun. 1982.

${ }^{107}$ Final Communiqué of the North Atlantic Council met in Ministerial Session at Brussels on 8th and 9th December 1983, para. 13.

${ }^{108}$ See Freeman, Security and the CSCE Process, 90-105. 